\title{
CSIGAKERÉK FOGFELÜLET MEGHATÁROZÁS SAJÁT FEJLESZTÉSÜ SZÁMÍTÓGÉPES PROGRAMMAL
}

\author{
Ábel József \\ PhD hallgató, Miskolci Egyetem, Matematikai Intézet, Ábrázoló Geometriai Tanszék \\ 3515 Miskolc, Miskolc-Egyetemváros, e-mail: abel.jozsef16@gmail.com
}

\begin{abstract}
Absztrakt
A mai technológiai körülmények között a számítógéppel támogatott vagy teljesen automatizált rendszerek veszik át a termékek és a gyártási eszközök tervezési folyamatait. A korszerü mérnöki munka számitógépes támogatása az egyik legfontosabb feltétel a termelés hatékonyságának növeléséhez és a termékek minöségének javitásához. A gyártás automatizálásának fejlesztését mozdíthatja elö a gyártásgeometria fejlesztésére kimunkált matematikai kinematikai modell kiterjesztésének lehetösége a projektív térmodellre, mely nemcsak a kúpos és hengeres helikoid felületeknek egy matematikai általánositása, hanem például a spiroid csiga gyártásakor a gyártási hibák kiküszöbölése terén is elörelépést mutat. Az analitikus geometriai szempontól egységes koncepció szerint konstruált modellezö program segíti a csigahajtópárok elemeinek bonyolult gyártásgeometriai fejlesztését. Jelen irásban, egy tengelymetszetben körív profilú csigához kapcsolódó kerék fogfelületi pontjainak meghatározása és modellezése kerül bemutatásra.
\end{abstract}

Kulcsszavak: matematikai kinematikai modell, gyártásgeometria, csigakerék, számitógépes modell.

\begin{abstract}
In today's technological environment, the computer-aided or fully automated systems take over the design processes of products and manufacturing equipment. Computer aided engineering activity is one of the most important condition for increasing of the production efficiency and enhancing the quality of the products. The development of the production automation can be advanced by the possibility of extending the mathematical kinematical model generated for the development of the production geometry to the projective space model, which is not only a mathematical generalization of the conical and cylindrical helicoid surfaces, but also progress in eliminating manufacturing errors. The modelling program, constructed according to a uniform concept from the analytical geometric viewpoint, helps the complex production geometry development of the elements of worm gear drive pairs. In this paper, the determination and modelling of the tooth surface points of a wheel connected to a worm with a circular arc profile in axial section is presented.
\end{abstract}

Keywords: mathematical kinematical model, production geometry, worm gear, computerized model.

\section{Bevezetés}

A DifiCAD Mérnökirodában müködő Csiga Tudományos Iskolában folyó gyártásgeometriai fejlesztések egyik kiemelten fontos területe a csigához kapcsolódó csigakerék fogfelületének modellezése, analitikus meghatározása és ezáltal a csigahajtás lettartamának, hatásfokának optimálása. A csigahajtópárok müködési jellemzőit egyéb tényezők mellett a kapcsolódó fogfelületek geometriai jellemzői határozzák meg. A tervezés során feladat a hidrodinamikai szempontoknak is megfelelő kapcsolódó 
felületek létrehozása. Cél a kenőfilm és a teherbíró hordfelületek kialakítása során, hogy a kapcsolódási mezön belül a pillanatnyi érintkezési görbék irányai a relatív sebességek irányával közel $90^{\circ}$-os szöget zárjanak be (Dudás I., 1991).

A csigahajtópár elemek gyártásának elméleti fejlesztésére kimunkált első, nemzetközileg is ismert matematikai kinematikai modellt a referencia henger és kúp közös alkotóra döntésével Dudás profeszszor készítette (Dudás I., 2000). A csigahajtópárok gyártásgeometriai fejlesztésére számos további, a munkámhoz kapcsolódó tudományos írás született napjainkban is (Dezső G., 2017), amelyek célja a csigák gyártási pontosságának növelése (Bercsey T., Horák P., 2007), csigahajtópárok méretezése (Felhő Cs. at al., 2004) és modellezése (Dudás L., 2010). A matematikai kinematikai modell egy továbbfejlesztett változata a referencia kúp és henger közös forgástengelyen történő elhelyezésével, azok közti projektív transzformációs kapcsolatra épült (Balajti Zs., 2016). A csiga és csigakerék kapcsolódásának vizsgálata komoly matematikai (Vadászné Bognár G., 2003), gépészeti (Litvin F., Fuentes A., 1994) és geometriai (Balajti Zs., 2017) háttérrel került vizsgálatra. Ez a cikk egy saját készítésű szoftverrel mutatja be a kúpos és hengeres csigák fogfelületének szintetikus és geometriai paramétereikkel analitikus modellezését, majd a továbbfejlesztett matematikai modellben a kapcsolódó kerék fogfelületi pontjainak meghatározását.

\section{A programról}

A hengeres és kúpos csigák matematikai szimulációját bemutató szoftver $\mathrm{C}$ programnyelven készült a továbbfejlesztett matematikai kinematikai modellben. A matematikai általánosítás eredményeként a csigák referencia hengere és kúpja centrális kollineációs kapcsolatban kerültek elhelyezésre.

A program szerkezetének kialakítása során egyik fö szempont az volt, hogy a programot használók számára a témakör átlátható és érthető legyen. A csavarfelület elméleti származtatása után továbbra is cél volt a lehető legegyszerübb és átláthatóbb megoldás. A kezelöfelület kialakítása könnyen átláthatóvá teszi a felhasználó számára a program által felkínált összes modellezési lehetőséget. A program sajátossága, hogy a hengeres és kúpos csigák referenciahengerét és referenciakúpját közös tengelyen elhelyezve lehetőség nyílik a legyártandó hengeres és kúpos csigák a modellezésén túl a projektív geometriai alapokon történő tárgyalására is (Balajti Zs., 2016).

A C programnyelv a rendszerszoftverek megvalósítására készült, széles körben használatos hordozható alkalmazásszoftverek fejlesztésére is. A C minden idők egyik legszélesebb körben alkalmazott programozási nyelve, befolyása volt számos más népszerü programozási nyelv kialakulására is, így az egyik kiterjesztése a $\mathrm{C}++$ programozási nyelv.

A C programozási nyelv könyvtárakat használ elsődleges kiterjesztésként. Minden könyvtárnak általában van egy fejlécfájlja, amely tartalmazza a könyvtárban található függvények prototípusait, amelyeket egy program használhat, valamint az ezekhez a funkciókhoz használt speciális adattípusok és makroszimbólumok deklarációit. Ahhoz, hogy a program könyvtárat használhasson, tartalmaznia kell a könyvtár fejlécfájlt, illetve a könyvtárat össze kell kapcsolni a programmal, amely sok esetben fordítói jelzőket igényel. A csatlakoztatott funkciók bármilyen jövőbeni gyártási folyamatok modelljei lehetnek.

\section{Kapcsolódási viszonyok}

A kúpos és hengeres csigahajtások elemeinek gyártásgeometriai fejlesztésére kimunkált matematikai kinematikai modell továbbfejlesztett verziójában a referencia kúp és henger közös forgástengelyen 
kerültek elhelyezésre, így a kúpos csigák megmunkálása esetén változó $\mathrm{a}=\mathrm{a}_{0} \pm \mathrm{p}_{\mathrm{r}} \cdot \varphi_{1}$ tengelytávval készült, ahogyan azt az 1. ábra szemlélteti.

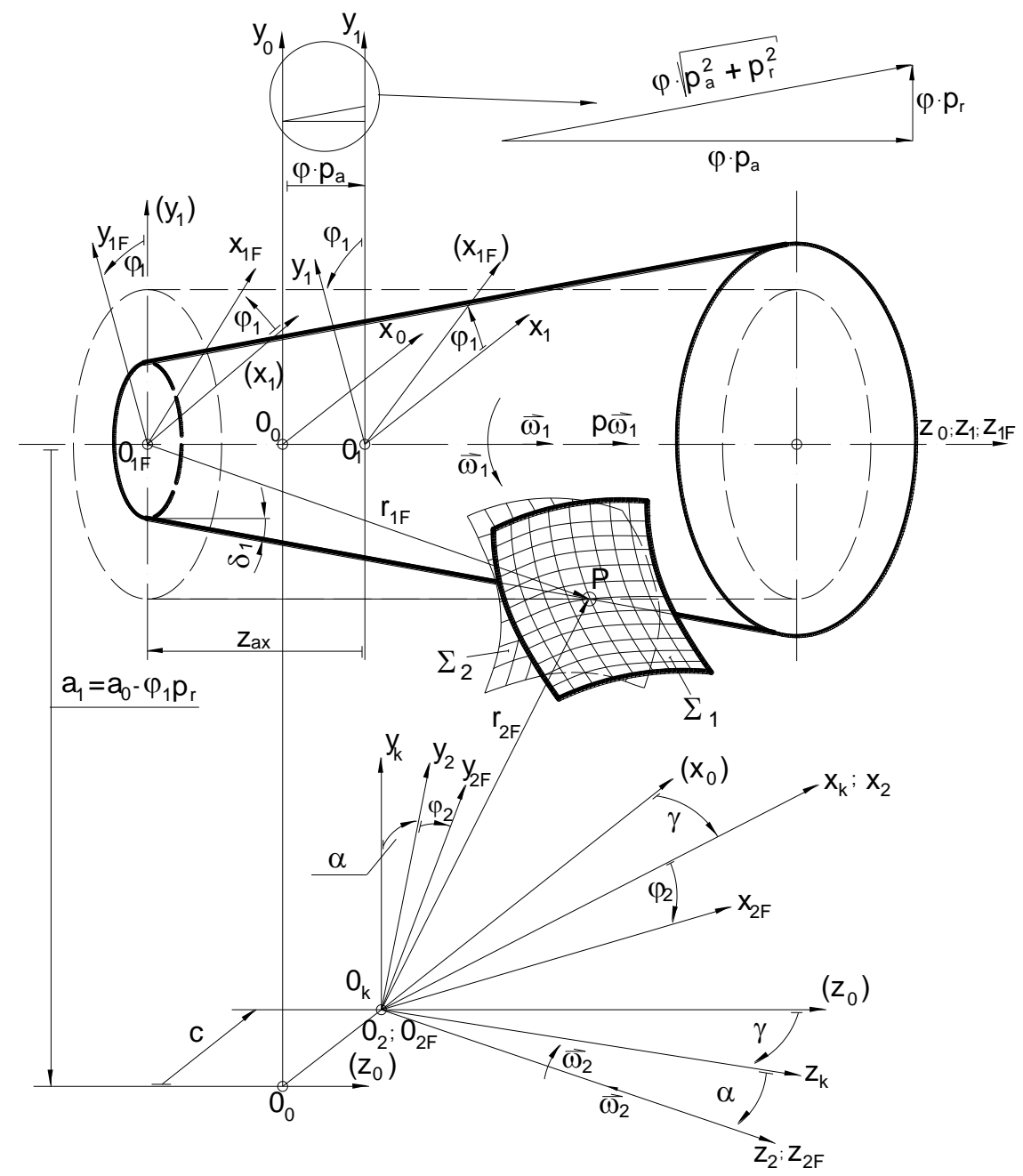

1. ábra. Koordinátarendszerek kapcsolata hengeres, illetve kúpos csavarfelületek és megmunkáló szerszámaik gyártáselméletének általános vizsgálatához (Balajti Zs., 2007)

A koordináta-rendszerek az alábbiak szerint kerültek értelmezésre:

$\mathrm{K}_{0}\left(\mathrm{x}_{0}, \mathrm{y}_{0}, \mathrm{z}_{0}\right) \quad$ álló koordinátarendszer

$\mathrm{K}_{1}\left(\mathrm{x}_{1}, \mathrm{y}_{1}, \mathrm{z}_{1}\right) \quad$ a lineáris mozgást végző gépasztalhoz kötött koordinátarendszer

$\mathrm{K}_{1 \mathrm{~F}}\left(\mathrm{x}_{1 \mathrm{~F}}, \mathrm{y}_{1 \mathrm{~F}}, \mathrm{z}_{1 \mathrm{~F}}\right)$ a csavarfelület koordinátarendszere, melyben meghatározásra kerül a csavarfelület $\eta, \vartheta$ paraméteres egyenlete

$\mathrm{K}_{2}\left(\mathrm{x}_{2}, \mathrm{y}_{2}, \mathrm{z}_{2}\right) \quad$ a szerszám álló koordinátarendszere, melynek $z_{2}$ tengelye illeszkedik a $z_{2 F}$ tengelyre

$\mathrm{K}_{2 \mathrm{~F}}\left(\mathrm{x}_{2 \mathrm{~F}}, \mathrm{y}_{2 \mathrm{~F}}, \mathrm{z}_{2 \mathrm{~F}}\right)$ a szerszámhoz, illetve kerékhez kötött forgó koordinátarendszer $\mathrm{K}_{\mathrm{k}}\left(\mathrm{x}_{\mathrm{k}}, \mathrm{y}_{\mathrm{k}}, \mathrm{Z}_{\mathrm{k}}\right) \quad$ segéd koordinátarendszer 
Alkalmazott paraméterek:
$\mathrm{a}=\mathrm{a}_{1} \quad$ tengelytáv
c a szerszám x irányú kiemelésének távolsága (pl. konvolut vagy evolvens csiga esetén a torokhenger, illetve alaphenger sugara)
$\mathrm{Z}_{\mathrm{ax}} \quad \mathrm{a}$ csiga álló koordinátarendszere kezdőpontjának $\mathrm{Z}_{1=\mathrm{Z}_{1 \mathrm{~F}}}$ tengelymenti koordinátája a csiga forgó koordinátarendszerében
$\varphi_{1} \quad$ a csavarfelület elfordulásának szöge, (szögelfordulási-, burkolási-, ill. mozgásparaméter)
$\varphi_{2} \quad$ a szerszám elfordulásának szöge (maró v. köszörükorong)
$\mathrm{i}_{21} \quad \mathrm{i}_{21}=\varphi_{2} / \varphi_{1}$ áttétel
$\gamma \quad$ a szerszám bedöntése a hengeres csavarfelület osztóhengeri menetemelkedési szögével
$\alpha \quad$ a szerszámnak a csavarfelület profiljára való döntésének a szöge a jellegzetes metszetben
$\mathrm{p} \quad$ a menetemelkedés csavarparamétere
$\mathrm{p}_{\mathrm{a}} \quad$ az axiális irányú csavarparaméter
$\mathrm{p}_{\mathrm{r}} \quad$ radiális irányú csavarparaméter

A matematikai kinematikai modell alkalmas a csavarfelületekkel érintkező kerék fogfelületének gyártásgeometriai és érintkezési viszonyainak vizsgálatára is.

A kerék felületének vizsgálata összefügg a hordkép, illetve a kapcsolókép vizsgálatával, melyet a kapcsolóvonalak és a kapcsolódási csomópontok erősen determinálnak (Lévai I. at al., 2009). A kapcsolási mező a kapcsolófelület müködő része, mely alapján érdemes meghatározni a csiga szükséges hosszúságát, illetve a csigakerék koszorúszélességét. A kapcsolófelületet az egymást kölcsönösen burkoló felületek érintkező görbéinek serege képezi az álló koordináta rendszerben.

\section{Kúpos csigák fogfelületének modellezése}

A program a különböző típusú kúpos csigák fogfelületeinek modellezésével segíti a tervezési folyamatot. Az egyenes alkotójú kúpos csavarfelületek közül az archimédeszi, involut és a konvolut felület modellezése is megvalósítható. A tengelymetszetben körív profilú kúpos csavarfelületek szintén modellezhetők a megfelelö paraméterválasztással, ahogyan az a 2. ábrán is látható. A C programozási nyelv biztosítja a további fejlesztések lehetőségét.

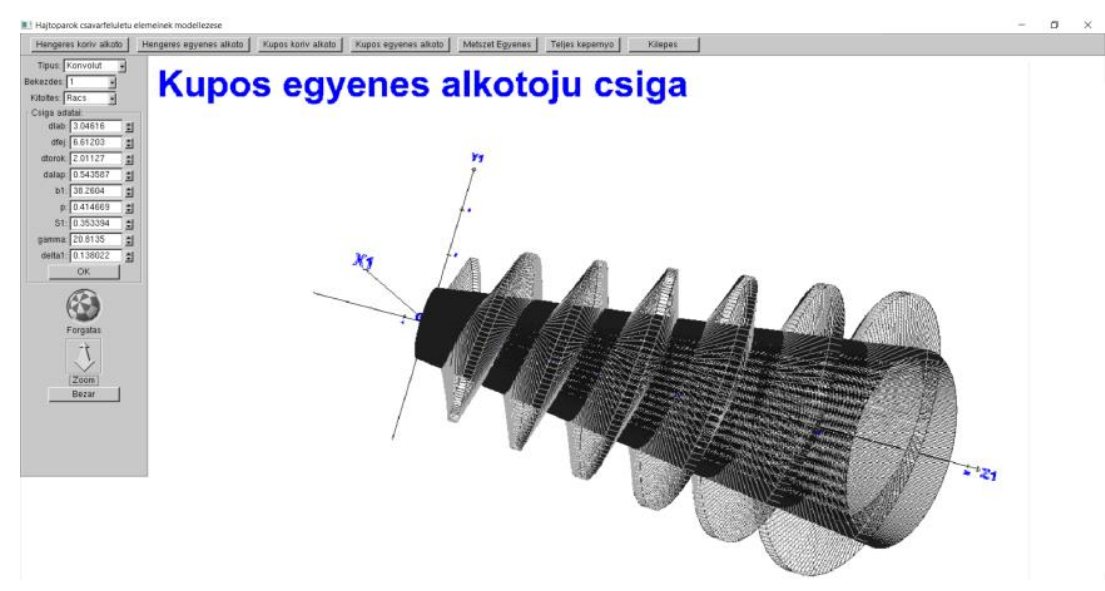

2. ábra. Egy egyenes alkotójú konvolut kúpos csavarfelület modellje 


\section{Hengeres csigák fogfelületének modellezése}

A program a különböző típusú hengeres csigák fogfelületeinek modellezésével is segíti a tervezési folyamatot. A hengeres egyenes alkotójú csavarfelületek közül az archimédeszi, involut és a konvolut felület modellezése is megvalósítható. A programban a helikoid felületek mind egyenes, mind tengelymetszetben körív profillal létrehozhatók, ahogyan az a 3. ábrán látható. A C programozási nyelv itt is biztosítja a további fejlesztések lehetőségét.

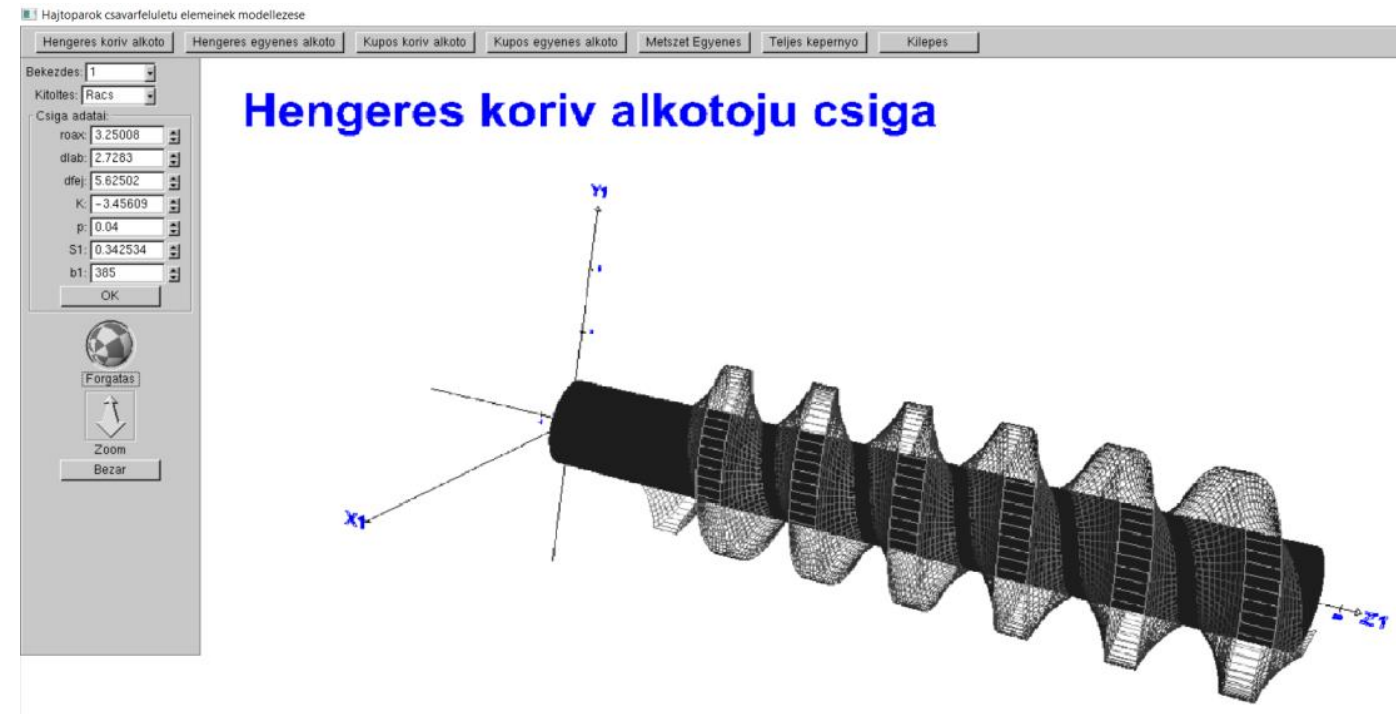

3. ábra. Egy tengelymetszetben körív profilú hengeres csavarfelület modellje

\section{Kapcsolódási viszonyok}

A $\Sigma_{l}$ csavarfelület $(\eta, \vartheta)$ felületi paraméter értékpárja egy $\mathrm{u} \in I \subseteq \mathbb{R}$ paraméter függvénye. A direkt eljárás során a csiga fogfelületének ismeretében a hajtópár viszonylagos mozgása által jön létre a burkolt kerék fogfelület. A kétparaméteres burkolás eredményezi a kapcsolódás érintkezési vonalait, melynek meghatározása (Balajti Zs., 2007) szerint történt.

A csiga fogfelülete az $(\eta, \vartheta)$ felületi paraméterekkel a $\mathrm{K}_{1 \mathrm{~F}}$ forgó koordináta-rendszerben

alakú, mely koordinátákra bontva az

$$
\underline{\mathrm{r}}_{1 \mathrm{~F}}=\underline{\mathrm{r}}_{1 \mathrm{~F}}(\eta, \vartheta)
$$

$$
\underline{\mathrm{r}}_{1 \mathrm{~F}}=\mathrm{x}_{1 \mathrm{~F}}(\eta, \vartheta) \cdot \underline{\mathrm{e}}_{\mathrm{x}}+\mathrm{y}_{1 \mathrm{~F}}(\eta, \vartheta) \cdot \underline{\mathrm{e}}_{\mathrm{y}}+\mathrm{z}_{1 \mathrm{~F}}(\eta, \vartheta) \cdot \underline{\mathrm{e}}_{z}
$$

alakban írható fel.

A csiga fogfelületi pontjaiban az $\underline{n}_{1 F}$ normálvektor az $(\eta, \vartheta)$ felületi paraméterek ismeretében

$$
\underline{\mathbf{n}}_{1 \mathrm{~F}}=\frac{\partial \underline{\mathrm{r}}_{1 \mathrm{~F}}}{\partial \eta} \times \frac{\partial \underline{\mathrm{r}}_{1 \mathrm{~F}}}{\partial \vartheta} .
$$

A csiga és kerék közös, $\underline{\mathrm{r}}_{1 F}$ helyvektorral jellemezhető fogfelületi érintkezési pontjában a köztük fellépő $\underline{\mathbf{v}}_{1 \mathrm{~F}}$ relatív sebességvektor a csiga $\mathrm{K}_{1 \mathrm{~F}}$ és a kerék $\mathrm{K}_{2 \mathrm{~F}}$ koordinátarendszere közti $\mathbf{M}_{1 \mathrm{~F}, 2 \mathrm{~F}}$ és $\mathbf{M}_{2 \mathrm{~F}, 1 \mathrm{~F}}$ transzformációs mátrixokkal a következő módon számítható 


$$
\underline{\mathrm{v}}_{1 \mathrm{~F}}=\mathbf{M}_{1 \mathrm{~F}, 2 \mathrm{~F}} \cdot \frac{\mathrm{d} \mathbf{M}_{2 \mathrm{~F}, 1 \mathrm{~F}}}{\mathrm{dt}} \cdot \underline{\mathrm{r}}_{1 \mathrm{~F}},
$$

ahol

$$
\mathbf{P}_{1 \mathrm{a}}=\mathbf{M}_{1 \mathrm{~F}, 2 \mathrm{~F}} \cdot \frac{\mathrm{d}}{\mathrm{dt}} \mathbf{M}_{2 \mathrm{~F}, 1 \mathrm{~F}}
$$

a kinematikai leképzés mátrixa.

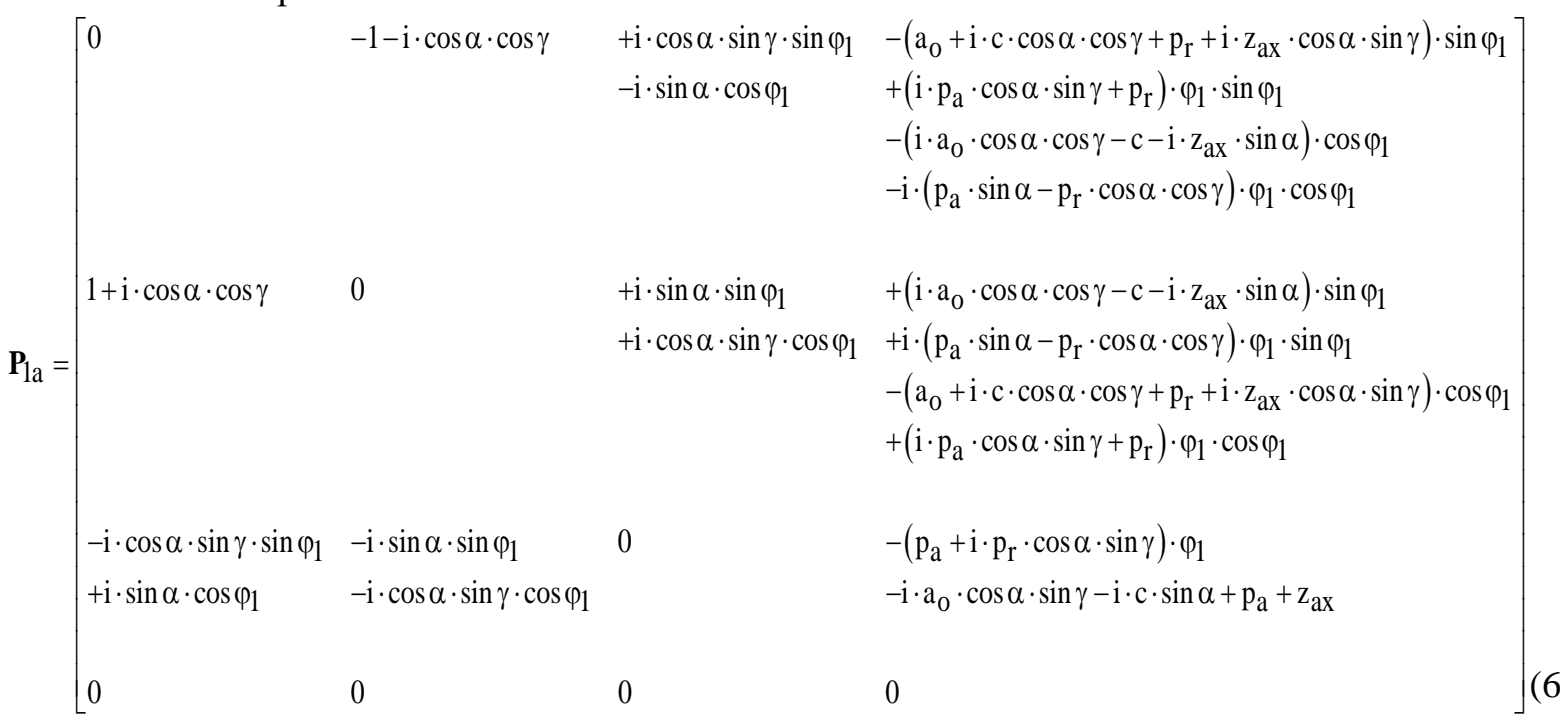

Az érintkezési vonalak egyenletét a kapcsolódás I. törvénye szerint a következő függvénykapcsolat írja le:

$$
\mathrm{f}\left(\mathrm{\eta}(\mathrm{u}), \vartheta(\mathrm{u}), \varphi_{1}\right)=\mathrm{f}\left(\mathrm{u}, \varphi_{1}\right)=\underline{\mathrm{n}}_{1 \mathrm{~F}} \cdot \underline{\mathrm{v}}_{1 \mathrm{~F}}=O
$$

Rögzített $\varphi_{1}$ mozgásparaméter értékek mellett kerültek meghatározásra a csiga fogfelületének azon összetartozó $(\eta(\mathrm{u}), \vartheta(\mathrm{u}))$ paraméter értékpárjai, amelyek teljesítik a (7) összefüggést.

Konkrét példaként a (Dudás I., 1991) M1. mellékletében geometriai paraméterekkel megadott tengelymetszetben körívprofilú hengeres csigahajtás kerül bemutatásra a 4. ábrán. A melléklet szerint méretezett és legyártott csigahajtás esetében a saját program modellezi a szokásos jelölések alkalmazása mellett egy-egy $\varphi_{1}$ mozgásparaméter érték esetén a $K_{A}$ és $K_{B}$ csomópontokon áthaladó érintkezési vonalakat.

A csigakerék $\Sigma_{2}$ fogfelülete a $K_{2 \mathrm{~F}}$ csigakerékhez rögzített koordinátarendszerben felírt pillanatnyi érintkezési vonalak burkolófelületeként számítható.

$$
\left.\begin{array}{l}
\mathrm{f}\left(\eta, \vartheta, \varphi_{1}\right)=0 \\
\underline{\mathrm{r}}_{1 \mathrm{~F}}=\underline{\mathrm{r}}_{1 \mathrm{~F}}(\eta, \vartheta) \\
\underline{\mathrm{r}}_{2 \mathrm{~F}_{-} \text {kerék }}=\mathbf{M}_{2 \mathrm{~F}_{-} 1 \mathrm{~F}} \cdot \underline{\mathrm{r}}_{1 \mathrm{~F}}
\end{array}\right\}
$$

A konkrét eset bemutatása az 5. ábrán látható.

A fentiekben vázolt eljárással bármely hajtástípusnál meghatározhatók a kerék fogfelületének pontjai. 


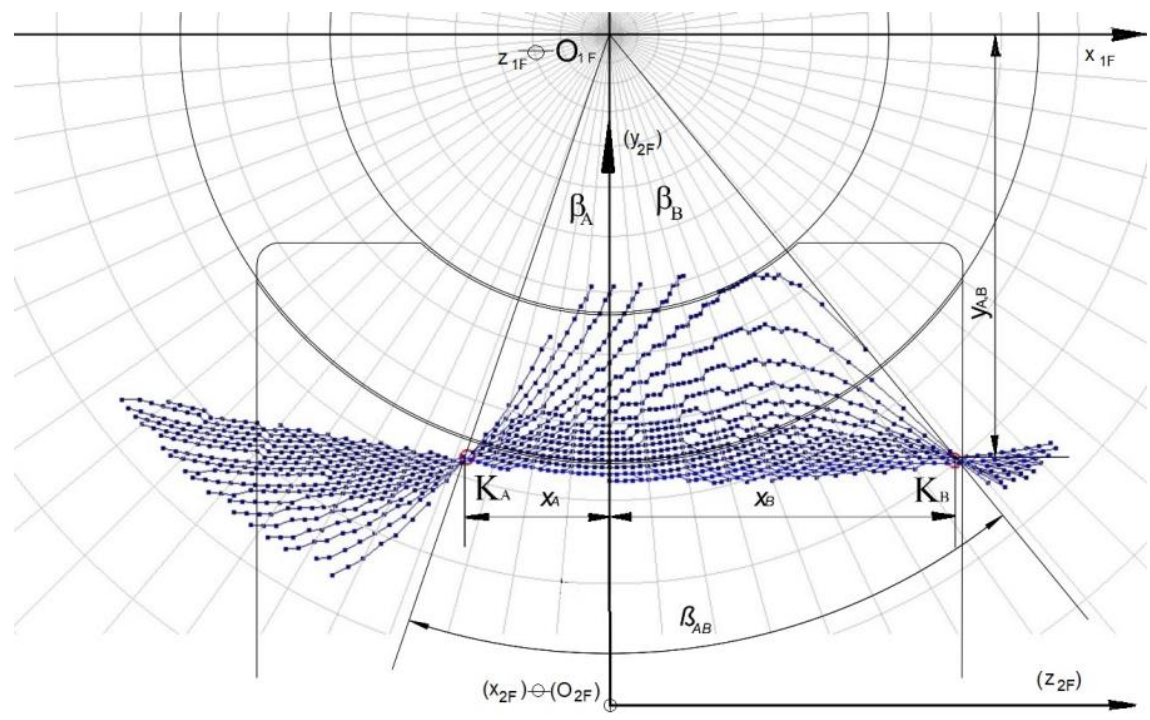

\begin{tabular}{|l|l|l|l|}
\hline \multicolumn{2}{|c|}{ Input: } & \multicolumn{1}{c|}{ Output: } \\
\hline $\mathrm{i}_{21}=0.0857142$ & Lábkör $=38.75 \mathrm{~mm}$ & $\eta_{\text {Start }}=35.75$ & $\mathrm{X}_{\mathrm{A}}=20.3389$ \\
$\mathrm{x}_{2}=1.0$ & Fejkör $58.75 \mathrm{~mm}$ & $\eta_{\text {Stop }}=88.75$ & $\mathrm{X}_{\mathrm{B}}=49.3389$ \\
$\mathrm{~K}=69.5 \mathrm{~mm}$ & $\varphi_{\text {IStart }}=-100.0$ & $\eta_{\text {Step }}=1.0$ & $\mathrm{Y}_{\mathrm{A}}=60.7890$ \\
$a=280.0 \mathrm{~mm}$ & $\varphi_{\text {IStop }}=250.0$ & $\vartheta_{\text {Start }}=-100.0$ & $\mathrm{Y}_{\mathrm{B}}=60.7890$ \\
$p_{o}=18.75$ & $\varphi_{\text {IStep }}=10.0$ & $\vartheta_{\text {Stop }}=+100.0$ & $\beta_{\mathrm{A}}=18.4993$ \\
$\rho_{a x}=50.0 \mathrm{~mm}$ & & $\vartheta_{\text {Step }}=1.0$ & $\beta_{\mathrm{B}}=38.8347$ \\
$\mathrm{Z}_{\mathrm{ax}}=0.0 \mathrm{~mm}$ & & nv<=0.001 & $\beta_{\mathrm{AB}}=57,3340$ \\
\hline
\end{tabular}

4. ábra. Érintkezési vonalak a bemenö geometriai paraméterekkel a tengelymetszetben körív profilú csigahajtás esetén

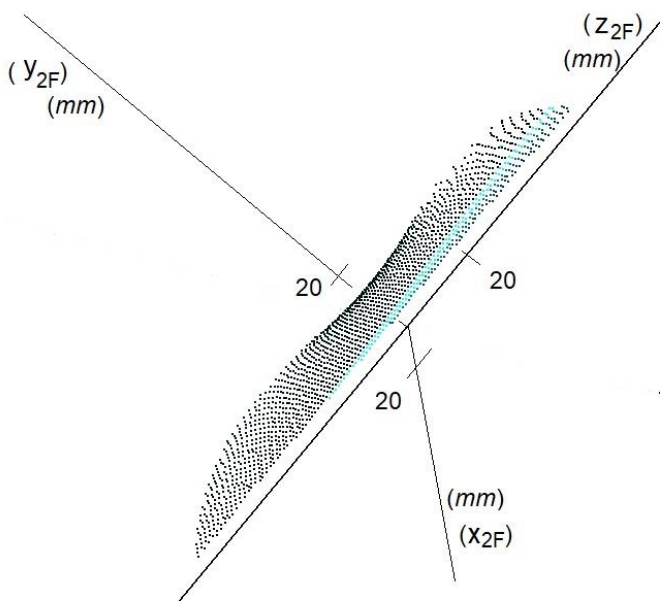

5. ábra. Kerék fogfelületi pontok térbeli elhelyezkedése a $K_{2 F}$ koordinátarendszerrel párhuzamos $\left(K_{2 F}\right)\left\{\left(x_{2 F}\right),\left(y_{2 F}\right),\left(z_{2 F}\right)\right\}$ koordinátarendszerben 


\section{7. Összegzés}

A kúpos és hengeres csigák egyenes és körív alkotójú fogfelületeinek modellezésére készített számítógépes program a fogfelület tervezését egyidejüleg szintetikusan és a csiga fogfelület alkotóját meghatározó geometriai paraméterekkel analitikusan is lehetővé teszi. A C programnyelven készített szoftverrel a kétparaméteres burkolás elvén kerülnek számításra a kúpos és hengeres helikoid felületek kapcsolódó felületei. Egy konkrét tervezett és legyártott csigához kapcsolódó csigakerék fogfelület pontjainak számítása után a térbeli elhelyezkedésük is bemutatásra került. Ezzel lehetősége nyílt a csiga fogfelületének és a hozzá kapcsolódó kerék fogfelületének geometriai jellemzőinek megválasztásával a csigahajtások élettartamának, müködésének és hatásfokának optimalizálására. A teljes matematikai elemzés a készülő $\mathrm{PhD}$ dolgozatom részét képezi.

\section{Köszönetnyilvánítás}

A cikkben ismertetett kutató munka a Miskolci Egyetemmel együttmüködési megállapodásban lévő DifiCAD Mérnökiroda támogatásával valósulhatott meg.

\section{Irodalom}

[1] Dudás, I. (2000) The Theory \& Practice of Worm Gear Drives. Kogan Page US. Sterling. USA. p. 320.

[2] Dudás, I. (1991) Csavarfelületek gyártásának elmélete. Akadémiai doktori disszertáció, Miskolc.

[3] Bercsey, T., Horák, P. (2002) Modelling of the contact and tribological relations of spatial gear pairs, International Conference on Gears. Munchen. pp. 91-105.

[4] Dezső G., Szigeti F. (2017) A müszaki szimulációs módszerek helye a mérnökképzésben, Müszaki Tudományos Közlemények 6:63-71. https://doi.org/10.33895/mtk-2017.06.07

[5] Felhő, Cs., Szentesi, A., Tóth, G. (2004) Geometrical Dimensioning of Worm Drives Proceeding of the 11th International Conference on Tools: ICT-2004. Miskolc, Hungary, University of Miskolc, pp. 177-182.

[6] Dudás, L. (2010) The effect of worm profile on contact lines. microCAD, XXIV. International Scientific Conference. Miskolc, Hungary, pp. 39-44.

[7] Balajti, Zs. (2016) Kapcsolódó felületpárok gyártásgeometriai fejlesztése, ábrázoló geometriai alkalmazással. Habilitációs Tézisfüzet. Miskolc. p. 80.

[8] Vadászné Bognár, G. (2003) Matematika informatikusok és műszakiak részére 2., Miskolc, Magyarország, Miskolci Egyetemi Kiadó, p. 347.

[9] Litvin, F. L., Fuentes, A. (1994) Gear Geometry and Applied Theory. Englewood Cliffs. Prentice Hall.

[10] Balajti, Zs. (2017) Hordképelemzés változó tengelytávú matematikai modellben, OGÉT, XXV. Nemzetközi Gépészeti Konferencia, Kolozsvár, pp. 51-54.

[11] Balajti, Zs. (2007) Kinematikai hajtópárok gyártásgeometriai fejlesztése. PhD diszertáció, Miskolc, 126. old.

[12] Lévai I., Dudás I., Balajti Zs. (2009) Homorú ívelt profilú (axiális metszetben kör) hengeres csiga geometriai méretezése, Gépgyártás Folyóirat, 4(5):30-35. 